\title{
Le jugement Chaoulli ou comment brader un droit public qui garantissait un droit aux individus
}

\author{
by FRANÇOIS BÉLAND \\ Université de Montréal
}

«Trouver une forme d'association qui défende et protège de toute la force commune la personne et les biens de chaque associé, et par laquelle chacun s'unissant à tous n'obéisse pourtant qu' à lui-même et reste aussi libre qu' auparavant.» Tel est le problème fondamental dont le contrat social donne la solution.

JEAN-JACQUES ROUSSEAU, Le contrat social, page 51

A présent, ce quion voulait, cétait que les dirigeants fussent identifiés au peuple... . La nation n'avait nul besoin d'être protégée contre sa propre volonté... . Mais...l'idée que les peuples n'ont pas besoin de limiter leur pouvoir sur eux-mêmes pouvait sembler axiomatique lorsqu'un gouvernement démocratique n'existait encore que dans nos rêves... Se protéger contre la tyrannie du magistrat ne suffit donc pas... . Trouver le juste milieu entre indépendance individuelle et contrôle socialest un domaine où presque tout reste à explorer... . Ce que doivent être ces règles est le problème majeur des sociétés humaines.

JOHN STUART MILL, De la liberté, page 65,67 
Le jugement Chaoulli ou comment brader un droit public qui garantissait un droit aux individus

$\mathrm{E}$ n Surface, les positions de Flood et Lewis(2005) et de Evans (2005) sur le jugement Chaoulli exposée dans leurs textes publiés dans ce numéro de Politiques de santé - Healthcare Policy se ressemblent. Le style de Evans est plutôt flamboyant, celui de Flood et Lewis, plutôt posé, mais les trois auteurs s'accordent pour condamner le jugement de la Cour suprême. Il est mal fondé en fait et en logique et l'arène juridique nest pas constituée pour s'y voir dérouler un débat essentiellement politique. Les deux textes se complètent aussi. Flood et Lewis analyse le contenu du jugement majoritaire pour critiquer l'usage qu'il fait des sciences sociales et de l'opinion des quelques médecins appelés à témoigner devant la Cour, analyse qui rejoint plusieurs de commentaires publiés dans la presse (Béland 2005) et sur des sites Internet canadiens (Longwoods eLetter 2005). Ils proposent quelques actions et mesures pour limiter les conséquences du jugement Chaoulli sur le régime canadien d'assurance maladie public et universel. Evans raconte l'histoire des budgets fédéral et provinciaux et du financement du régime d'assurance maladie depuis les années 1970, en notant ici et là les occasions manquées délargir la couverture du régime aux services autres que strictement médicaux et hospitaliers.

Nos trois protagonistes s'opposent sur la suite des choses. Flood et Lewis se perdent en conjecture sur les façons de limiter les dégâts. Ont-ils exclus le recourt à la clause dérogatoire par principe ou par réalisme? Evans le propose sans état d'âme et sans illusion-le gouvernement libéral actuel du Québec a refusé d'y recourir. [Vous souvient-il de cet autre gouvernement libéral du Québec qui l'a invoquée à l'occasion de l'examen de quelques articles d'une loi linguistique invalidés par la Cour suprême? Quelques premiers ministres provinciaux, disciples hypnotisés de Trudeau (encore lui!), ont définitivement diabolisé la clause dérogatoire et trouvé une raison de plus de faire échouer l'accord du Lac Meech.]

Le Canada tout entier s'est enferré dans l'extrême de la logique libérale sur la question de la Charte des droits de telle sorte que tout recourt à la clause dérogatoire est anathème. Toute déclaration des juges de la Cour suprême depuis les Chartes québécoise ou canadienne devient automatiquement sacralisé, les juges fussent-ils dans l'erreur. Le débat, qui doit être continu, sur l'équilibre entre indépendance individuelle et contrôle social est dès lors émasculé.

Et cette fois-ci, les juges de la majorité y sont tombés dans l'erreur. La question est la suivante : est-ce que M. Zeliotis, celui au nom duquel tout ça a eu lieu, a souffert de la tyrannie de la majorité en ne pouvant souscrire à une assurance privée? Les cours du Québec et les juges de la minorité de la Cour suprême ont noté que M. Zeliotis navait pas de cause. Dans son cas précis, il a été établi que le retard à obtenir des soins dépendait de sa condition physique et psychologique et des retards qu' il a lui-même provoqués. Les juges de la majorité se sont aussi abstenus de se demander si M. Zeliotis, aurait eu accès à une assurance privée, puisqu'il sest enquis d'une telle assurance après le diagnostic médical, pas avant. 
Le droit de M. Zeliotis de recourir à l'assurance privée est examiné par la Cour en fonction des effets des délais d'attente dans le régime public sur sa santé et sa sécurité (Chaoulli c. Québec, 2005). Or, le droit de M. Zeliotis d'obtenir des soins est un droit créé par la présence d'un régime public et universel d'assurance maladie. Ce droit nexisterait tout simplement pas si le Canada en était encore aux régimes privés d'assurance-maladie. En conséquence, la Cour suprême a reconnu à $\mathrm{M}$. Zeliotis, et à tous les québécois, le droit de souscrire à un régime d'assurance privée parce qu'ils ne pourraient pas obtenir des soins requis assez rapidement sous un régime public, tandis que ce droit universel n'existe tout simplement pas dans un régime d'assurance privé, régime que la Cour suprême promeut! $\mathrm{M}$. Zeliotis ná donc pas souffert de la tyrannie de la majorité. Au contraire, l'existence d'un droit collectif, soit la couverture universel et public des services médicaux et hospitaliers, est la seule garantie qui existe pour assurer l'exercice d'un droit individuel, soit l'accès raisonnable à ces services. Ici, le contrat social offre toute la protection nécessaire contre la volonté de quelques-uns de le pervertir à leur profit. Un peu plus de Jean-Jacques Rousseau, un peu moins de John Stuart Mill, ferait l'affaire. Conclusion : il y a dans ce cas tyrannie de magistrats, ceux et celles de la Cour suprême. Tout justifie le recours par le gouvernement du Québec à la clause dérogatoire.

Les juges sont des magistrats, et quoique l'on puisse dire de la théorie de la séparation des pouvoirs, les juges sont nommés par le politique et font parti de l'appareillage qui nous gouverne. À ce titre, il y a tout aussi bien nécessité de protéger le peuple contre leur tyrannie que de celle des politiques. Et dans le cas Chaoulli qui nous occupe, le jugement majoritaire est suffisamment mauvais pour que l'équilibre des pouvoirs, cette question jamais résolue, réclame que la «magistrature politique», soit le Parlement, protège le peuple contre les excès de la «magistrature juridique». Puisse l'appel d'Evans ait quelques échos et que sen suive une révision de la sacralisation des juges et la levée de l'anathème sur la clause dérogatoire.

Stoïques devant la mystique juridico-politique de la sacralisation des Chartes, Flood et Lewis en sont réduits à des propositions dont quelques-unes ne laissent pas de me surprendre. Je nén mentionnerai qu'une seule. Les auteurs insistent pour qu'Ottawa impose aux provinces un système de gestion de listes d'attente. Et je vois d'ici tous mes bons amis du Canada anglais opiner du bonnet. Quelle ironie! Les inepties d'un appareil de gouvernement fédéral, la Cour suprême, seraient corrigées par l'accroissement des pouvoirs d'un autre appareil fédéral, soit le politique, tandis la province du Québec avait fait son devoir en interdisant les régimes d'assurance privée et que les cours du Québec avaient rejeté les prétentions de Chaoulli et Zeliotis. Qui plus est, le Québec a implanté récemment une série de mesures pour assurer une gestion efficace des plaintes des citoyens. Flood et Lewis proposeront-ils, chaque fois qu'un organisme fédéral gaffe, une invasion par un autre organisme fédéral d'un champ de juridiction provincial? Je ne comprends pas cette obsession de plusieurs de vouloir 
accroître le pouvoir des fédéraux dans le domaine de la santé. L' Australie, l'autre gouvernement fédéral qui possède de vastes pouvoirs dans le domaine de la santé, a-t-elle une histoire si exemplaire qu'un fédéralisme centralisateur apparaît tout de go comme supérieur au régime canadien plus décentralisé? Pourtant, la répartition décentralisée du pouvoir au Canada interdit à tout gouvernement fédéral de rayer d'un trait de plume notre régime public dans toutes les provinces, comme la droite australienne l'a pratiqué systématiquement depuis plus d'un quart de siècle.

Les propositions à plus long terme de Flood et Lewis ont plus de sens. Sans les nommer une à une, signalons quélles soulignent la nécessité de śassurer que le régime public et universel d'assurance maladie śadapte à l'évolution des besoins de soins de la population et au développement des sciences et de la technologie de la santé. On a vu monté l'insatisfaction de la population canadienne vis-à-vis le régime au cours des dernières années. Il n'est pas faux de voir dans le jugement majoritaire de la Cour suprême un ras-le-bol populiste, certes, mais réel. L'appui au régime public et universel peut se fragiliser rapidement. Evans souligne assez que le régime coûte cher aux riches, plus en santé que les autres. Les données de Mustard et al (1998) montrent aussi comment à partir du cinquième décile des revenus la contribution fiscale au régime est égale ou inférieure aux bénéfices que ces gens en tirent. Il suffit d'un coup de bascule pour que leur appui évapore: des dépenses publiques insuffisantes pendant un assez grand nombre d'années, l'effritement de l'idée canadienne d'un bon gouvernement qui tient de la logique du contrat social plutôt que de la maximisation du bonheur individuel, soit l'élection, ne serait qu'en désespoir de cause, d'un gouvernement fédéral conservateur, soit le maintien pendant quelques années encore d'un gouvernement MartinStronach, soit quelques scandales et négligences ici et là. On sillusionne à penser que cette conjonction d'évènements est tout simplement improbable. Aussi, plutôt que d'invoquer comme une incantation, à chaque coup dur, l'identité canadienne investit dans le régime d'assurance maladie, il vaudrait mieux, pour le défendre, investir dans le régime lui-même.

\section{RÉFÉRENCES}

Béland F (2005), La Cour suprême du Canada a raté une belle occasion de se taire, Le Devoir, 29 juin. Chaoulli c. Québec, Cour suprême du Canada, 2005, CSC 35, Para. 27, 29, 34, 35,37 à 43.

Longwoods eLetter (2005) Commentaries on The Supreme Court Decision: Chaoulliv. Quebec $<$ http://www.longwoods.com/products.php?producted $=173458$ page $=1>$

Mustard CA, Barer ML, Evans RG, Horne J, Mayer T et Derksen S (1998) Paying taxes and using healthcare services. The distributional consequences of tax financed universel health insurance in a Canadian province, Étude présentée à la Conférence sur le niveau de vie et la qualité de vie au Canada, Centre détude des niveaux de vie, Ottawa 20-31 octobre, [htpp://www.csls.ca/oct/ must1.pdf]

Rousseau JJ (1966[1763]), Du contrat social, Paris, Garnier-Flammarion

Stuart-Mill, J(1990[1859]), De la liberté, Paris, Gallimard 


\title{
The Chaoulli Judgment or How to Sell Off a Public Right
}

\begin{abstract}
The problem is to find a form of association which will defend and protect with the whole common force the person and goods of each associate, and in which each, while uniting bimself with all, may still obey himself alone, and remain as free as before. This is the fundamental problem of which the Social Contract provides the solution.
\end{abstract}

JEAN-JACQUES ROUSSEAU, The Social Contract

What was now wanted was, that the rulers should be identified with the people.... The nation did not need to be protected against its own will... But...the notion, that the people have no need to limit their power over themselves, might seem axiomatic, when popular government was a thing only dreamed about... Protection, therefore, against the tyranny of the magistrate is not enough... How to make the fitting adjustment between individual independence and social control - is a subject on which nearly everything remains to be done... What these rules should be, is the principal question in buman affairs.

JOHN STUART MILL, On Liberty

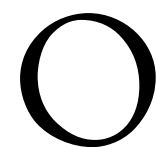

N The surface, the positions of Flood and Lewis and Evans on the Chaoulli judgment, expounded in their articles for this issue of Healthcare Policy/Politiques de santé, are quite similar. Although Evans's style is rather flamboyant, and while Flood and Lewis's is more staid, all three agree in their condemnation of the Supreme Court's judgment. The Chaoulli judgment is factually and logically flawed, and the legal arena is not set up to hold an essentially political debate. The two texts also complement one another. Flood and Lewis analyze the majority judgment and criticise the use it makes of social sciences and the opinion of a few physicians who testified before the Court. Their analysis reflects many commentaries that have been published in the press (Béland 2005) and on Canadian Internet sites (Longwoods eLetter 2005). They suggest some actions and steps to take to limit the consequences of the Chaoulli judgment on Canada's public and universal medicare system. Evans relates the history of federal and provincial budgets and of medicare 
funding since the 1970s and notes the missed opportunities to extend medicare coverage beyond strictly medical or hospital services.

The authors then disagree on what will follow. Flood and Lewis get lost in conjecture about ways to limit the damage. Do they avoid mentioning the notwithstanding clause as a matter of principle or realism? Evans certainly suggests its use without qualms. As a matter of fact, the current Liberal government of Quebec refused to use the notwithstanding clause. [Remember the other Liberal government of Quebec that invoked the use of the notwithstanding clause after a few sections of a language law were struck down by the Supreme Court? A few provincial premiers, mesmerized Trudeau followers (him again!) definitely demonized the notwithstanding clause and found one more reason to sink the Meech Lake Accord.]

The entire country got so caught up in the extremes of the Liberal logic on the Charter of Rights issue that any recourse to the notwithstanding clause is anathema. Any one statement made by the Supreme Court judges since the adoption of the Quebec and Canadian Charters automatically becomes enshrined, even when the judges are wrong. The debate, which must be ongoing, on the balance between individual freedom and social control is emasculated from that moment on.

And this time, the judges in the majority were wrong. The question is this: did Mr. Zeliotis, the man for whom all of this happened, suffer from the tyranny of the majority by not being able to buy private insurance? The Quebec courts and the Supreme Court minority judges observed that Mr. Zeliotis did not have cause of action. In his specific case, it was established that the delay in obtaining care was a result of his physical and psychological state and delays which he himself caused. The majority judges also abstained from asking themselves if $\mathrm{Mr}$. Zeliotis would have access to private insurance since he inquired about private insurance after his medical diagnosis, not before.

The Court weighed Mr. Zeliotis's right to use private insurance against the consequences of waiting times in the public system on his health and safety (Chaoulli v. Québec, 2005). Yet, Mr. Zeliotis's right to obtain healthcare is a right created by the presence of a public and universal medicare system. This right would simply not exist if healthcare insurance were still available only through private carriers on a private market in Canada. As a result, the Supreme Court recognized Mr. Zeliotis's right, as well as the right of all Quebecers, to buy private coverage since he could not obtain the required healthcare fast enough under the public system, even though this universal right simply does not exist in a private insurance system, a system which the Supreme Court promotes! Therefore, Mr. Zeliotis did not suffer from the majority's tyranny. On the contrary, the existence of a collective right, that is, universal and public coverage of medical and hospital services, is the only guarantee that exists to ensure that an individual right can be exercised, that is, reasonable access to those services. Here, the social contract offers all the necessary protection against the will of a few who want 
to corrupt it for their benefit. A little more Jean-Jacques Rousseau, a little less John Stuart Mill, would do. Conclusion: this is a case of the tyranny of judges, the judges of the Supreme Court. The Quebec government is fully justified to use the notwithstanding clause.

Judges are magistrates, and whatever is said about the separation of powers theory, judges are appointed through politics and are part of the machinery that governs us. It is therefore just as necessary to protect the nation from judges' tyranny as it is to protect the nation from politicians. In the case of Chaoulli, the majority judgment is bad enough that the balance of power, that never resolved issue, demands that the "political magistrates" (Parliament) protect the nation against the excesses of the "legal magistrates." May the echoes of Evans's appeal be heard, the judges's enshrinement reviewed and the curse on the notwithstanding clause lifted.

Stoic before the legal-political enshrinement of the Charters, Flood and Lewis can only make suggestions, a few of which cannot but surprise me. I will mention only one. The authors insist that Ottawa impose a waiting-list management system on the provinces. I can picture all my good friends from English Canada nodding in agreement. How ironic! The ineptitudes of a federal governmental machine, the Supreme Court, would be corrected by enhancing the powers of another federal machine, that is, the political one. However, Quebec carried out its duty by banning private insur-

ance systems, and the Quebec courts rejected the claims of Chaoulli and Zeliotis. Furthermore, Quebec recently implemented measures to manage citi-

whatever is said about the separation of powers theory, judges are appointed through politics and are part of the machinery that governs us zens's complaints effectively. Will Flood and Lewis suggest every time a federal body blunders that another federal body take over a provincial jurisdiction? I do not understand this widespread obsession with enhancing federal power in healthcare. Does Australia, which also has a federal government with vast powers in healthcare, have such an exemplary history in healthcare policy that a centralizing federalism appears so clearly superior to the more decentralized Canadian system? Yet, the decentralized division of power in Canada prevents any federal government from wiping out every provincial medicare program with a stroke of a pen as the Australian right-wing has systematically done for over a quarter-century.

Flood and Lewis's long-term suggestions make more sense. Without going through them one at a time, let me point out that they stress that the public and universal medicare system must adapt to the changing healthcare needs of the population 
and to the advancement in health and technology sciences. Canadians have shown increasing dissatisfaction with the system over the last few years. It would be fair to speculate that the majority judgment of the Supreme Court is a populist but genuine reflection of that disgust. Support for public and universal medicare can quickly dwindle. Evans also points out that the system is costly for the rich, who are healthier than others. The data from Mustard et al. (1998) also show that, as of the fifth income decile, tax dollars paid into the healthcare system are equal to or less than the benefits taxpayers reap from healthcare. It wouldn't take much to tip the scales and lose their support: too little public expenditure over too many years, or the erosion of the Canadian idea that a good government is founded on the logic of social contract rather than on the maximization of individual happiness, or an election, out of despair, of a Conservative federal government, or a few more years of a Martin-Stronach government, or some scandals and negligence here and there. We are fooling ourselves if we think that these events are unlikely. Rather than constantly bringing up medicare and the Canadian identity over and over again like some kind of incantation every time the medicare system gets hit, it would be wiser, in the interest of defending it, to invest in the system itself.

\section{REFERENCES}

Béland, F. (2005). La Cour suprême du Canada a raté une belle occasion de se taire. Le Devoir, 29 June.

Chaoulliv. Québec, Supreme Court of Canada, 2005, SCC 35, Para. 27, 29, 34, 35, 37 to 43. Longwoods eLetter (2005) Commentaries on The Supreme Court Decision: Chaoulliv. Quebec $<$ http://www.longwoods.com/products.php?producted $=17345$ \&page $=1>$

Mustard, C.A., Barer, M.L., Evans, R.G., Horne, J., Mayer, T. and Derksen, S. (1998). Paying taxes and using healthcare services. The distributional consequences of tax financed universal health insurance in a Canadian province, Study presented at the Centre for the Study of Living Standards Conference, "The State of Living Standards and the Quality of Life in Canada."

Ottawa, 20-31 October, [htpp://www.csls.ca/oct/must1.pdf]

Rousseau, J.J. (1966[1763]). The Social Contract. Paris: Garnier-Flammarion

Mill, J.S. (1990[1859]). On Liberty. Paris: Gallimard 